\title{
Contractionary depreciations in Latin America during the 2000s
}

\author{
Depreciações contracionistas na \\ América Latina durante os anos 2000
}

MARTÍN MONTANÉ*

EMILIANO LIBMAN**

GUIDO ZACK***

\begin{abstract}
RESUMO: Este artigo explora os efeitos da desvalorização cambial sobre o produto dos principais países latino-americanos que usam as Metas de Inflação há quase duas décadas. Construímos modelos VAR para Brasil, Chile, Colômbia, México e Peru nas últimas duas décadas e descobrimos que as depreciações têm efeitos contracionistas de curto prazo no Brasil e no México. Ilustramos algumas das implicações de política dessa descoberta construindo um modelo simples e mostramos que os efeitos contracionistas das depreciações podem ter efeitos desestabilizadores quando a política monetária é conduzida usando uma regra de Taylor padrão.
\end{abstract}

PALAVRAS-CHAVE: Metas de inflação; autoregressões de vetores; efeitos contracionistas das desvalorizações; regras de política monetária.

ABSTRACT: This paper explores the effects of currency depreciations on output for the main Latin American countries that have been using Inflation Targeting for almost two decades. We construct VAR models for Brazil, Chile, Colombia, Mexico and Peru for the last two decades and we find that depreciations have short-run contractionary effects in Brazil and Mexico. We illustrate some of the policy implications of that finding by building a simple model, and we show that contractionary effects of depreciations may have destabilizing effects when monetary policy is conducted using a standard Taylor Rule.

KEYWORDS: Inflation targeting; vector autoregressions; contractionary effects of devaluations; monetary policy rules.

JEL Classification: E31; E52; E58.

\footnotetext{
* Universidad Torcuato Di Tella (UTDT), Buenos Aires-Argentina. E-mail: martinmontaneb@gmail.com. Orcid: https://orcid.org/0000-0001-6255-2861.

** Universidad Nacional de San Martín (UNSAM), San Martín-Argentina. E-mail: emilianolibman@ gmail.com. Orcid: 0000-0001-7126-479X.

*** Universidad de Buenos Aires y Universidad Nacional de San Martín, Buenos Aires/Argentina. E-mail: zack.gui@gmail.com. Orcid: 0000-0002-5428-3240. Submitted: 15/June/2020; Approved: 18/ November/2020.
} 


\section{INTRODUCTION}

Inflation Targeting has become a popular choice. The number of countries that have adopt it the framework has been increasing steadily over the past three decades, including low- and middle-income economies. During the late 1970s, Latin American countries liberalized capital flows, and after a period were hard pegs were common (the 1990s), flexible exchange rate regimes become increasingly more popular. Since the late 1990s, several Latin American countries have adopted a policy framework that involves high capital mobility with relatively flexible exchange rate regimes and Inflation Targeting. The most important cases are Brazil, Chile, Colombia, Mexico and Peru (see Barbosa-Filho, 2015; Dancourt, 2015; FfrenchDavis, 2015; Ocampo and Malagón, 2015; Oreiro et al., 2009; Ros, 2015).

The popularity of Inflation Targeting is related to its presumed ability to anchor inflationary expectations without incurring in significant output and employment costs. The literature argues that if monetary policy is sufficiently sensitive with respect to changes in the rate of inflation, setting a short-run interest rate at the correct level is enough to achieve macroeconomic stability (Blanchard and Galí, 2007).

The literature also presumes that Inflation Targeting works smoothly in an open economy set-up. Because the central bank needs to adjust the domestic interest rate to achieve macroeconomic stability and it is assumed that a high degree of capital mobility is desirable, the exchange rate should be allowed to float. The implicit presumption is that exchange rate movements are not destabilizing, and in particular that depreciations are assumed to be expansionary both in the long- and in the short-run.

The hypothesis that devaluations have contractionary effects was formulated during a period were fixed exchange rate and low capital mobility was the norm (Diaz Alejandro, 1963, 1965; Krugman and Taylor, 1978), but there are good reasons to believe that the contractionary effects have not disappeared. Although exchange rate regimes are much more flexible than in the past, central banks intervene very often in the foreign exchange market to avoid undesirable exchange rate fluctuations. Moreover, as documented by Barbosa-Filho (2015) and Ros (2015) for the cases of Brazil and Mexico, monetary policy has been used to prevent large depreciations, but fewer interventions have been conducted to avoid appreciations (Libman, 2018a). This suggest that policy makers in those countries fear the negative repercussions of large exchange rate depreciations, but they welcome the expansionary effects from appreciations.

Consider the case of Brazil during the last decades. When the real exchange rate depreciated, ${ }^{1}$ inflation accelerated, while output remained stagnant, both during

\footnotetext{
${ }^{1}$ In this paper we follow the Latin American convention. We define the nominal exchange rate as the number of units of the domestic currency that are needed to buy a unit of the foreign currency. A depreciation means that the exchange rate goes up, and so on. Because the original literature on
} 
2002-2003, and more recently, in 2014-2016 (Serrano and Summa, 2016). Although factors such as fiscal policy and terms of trade were probably at play, this suggests that depreciations have contractionary effects. Galindo and Ros (2008) explored the recent Mexican case. Using VAR analysis, they found that devaluations have a weak contractionary effect on output, at least in the short-run.

Both Brazil and Mexico have experienced slow growth. In contrast, the Peruvian economy has been performing quite well; growth has been fast, while inflation has remained low and stable. Peru is well-known for its highly dollarized financial system and the Inflation Targeting regime that was adopted during the early 2000s was designed on the assumption that devaluations reduce output. Because exchange rate depreciations exert a negative effect on the balance sheet of banks, the Taylor Rule was complemented with frequent interventions in the foreign exchange market, as well as with other unconventional monetary policy tools (such as reserve requirements for dollar denominated deposits), to curtail excessive exchange rate volatility.

Inspired by the different performance of main Latin American economies that have adopted Inflation Targeting, this paper ask what are the implications associated with the presence of contractionary effects of depreciations when Inflation Targeting is operative. ${ }^{2}$ To understand the nature of the problem, consider for example a shock that implies appreciation of the nominal exchange rate that translates into a real appreciation (which is the case if inflation is low or moderate, see Taylor and Taylor, 2004). If demand depends negatively on the real exchange rate, the most likely case when depreciations are contractionary, then the appreciation generates further demand pressures. Because the increase in demand may generate some pressures on output and employment and consequently on prices, or because the central bank also includes the output gap in its monetary policy rule, playing by the rules of Inflation Targeting requires an increase in the real interest rate. Consequently, the nominal and the real exchange rate appreciates even more, expanding aggregate demand, and so. The system is thus not stabilized unless the monetary policy rule is complemented by other policy tools. Output and inflation can be more volatile than under an alternative policy regime were the effects of exchange rate shocks are adequately taken into account.

This paper attempts to shed additional light on this issue. A short summary of the main contributions and results is as follows. After providing an update review of the literature, we construct a family of VAR models for the main Latin American

contractionary devaluations was developed for a world of fixed or semi-fixed exchange rates, the term "devaluation" was more appropriate. Here we use "depreciations" ("appreciations") for exchange rate changes under more or less flexible exchange rate regimes, and "devaluations" ("revaluations") for changes when the exchange rate is fixed or semi-fixed.

2 To clarify, we do not have a mind a scenario where output contracts because the central bank raises interest rate after an exchange rate shock that increases inflation. Rather, we suggest that the presence of direct contractionary effects is problematic (i.e., a multiplicity of equilibrium path or instability may emerge when these effects are present). 
countries that have adopted Inflation Targeting. ${ }^{3}$ We find evidence that supports the view that devaluations are short-run contractionary (for about 2 to 8 quarters, depending on the specification adopted and the country). The results are statistically significant at standard levels in Brazil and Mexico. Because these effects are short-run in nature, they do not necessarily contradict large and growing body of papers that suggest that the level of the real exchange rate is positively correlated with economic growth (see Bresser-Pereira, 2012, 2013; Gabriel et al., 2020; Missio et al., 2015; Oreiro and Da Agostini 2017; Oreiro and Santana, 2018; Rodrik, 2008; and Razmi et. al., 2012).

Additionally, we build a stylized and we show that contractionary effects can destabilize the system if interest rates exert a strong pressure on the real exchange rate, and if the effects of depreciations on output are strongly contractionary, provided that these effects are not compensated with the direct effects of the real exchange rate on prices. This does not imply that Inflation Targeting is unstable. Instead, it suggests that the unconventional policies which have been adopted in Latin America (most notably by Peru) that delink the evolution of the exchange rate from the interest rate, such as a capital controls, prudential regulations or interventions in the foreign exchange market, can be of great help. An Inflation Targeting regime that ignores the negative repercussions of large exchange rate shocks may underperform, as it may have happened in the Brazilian and Mexican cases.

This paper is structured as follow. After this introduction, the next section reviews the related literature. The third section presents estimations based on VAR models. The fourth section develops our toy model. Finally, the last section concludes.

\section{LITERATURE REVIEW}

This section reviews the related literature on Inflation Targeting and on contractionary effects of devaluations. Inflation Targeting is now an integral part of the core macroeconomic models. Most central bank's target inflation using a short-term interest rate, without tracking the evolution of the money stock. Woodford (2003, chapters 2, 3 and 4) shows how to specify models where there is no money stock at all. The most remarkable result of this new literature is the idea that the equilibrium path is uniquely defined if the policy short-term interest rate is sufficiently

\footnotetext{
${ }^{3}$ To complete the background, Chile and Colombia are among the most stables economies in the region. Both adopted Inflation Targeting regimes in 1999, but in slightly different situations. While Chile already had a very low inflation rate of around 3\%, Colombia inflation rate was much higher (around 15\%) and the central bank was looking to consolidate the disinflation trend. Both countries currently have low inflation rates and a very low pass-through from exchange rates to prices. This also reduces the negative effect of exchange rate depreciations on growth, and could be the reason why their interventions in the foreign exchange markets has been less frequent than in other Latin American countries, especially in the Chilean case.
} 
sensible with respect to changes in the rate of inflation (Romer, 2000). This is known as the "Taylor-Principle".

In an open economy set-up, because a high degree of capital mobility is taken for granted, in order to employ monetary policy for domestic stabilization purposes, the exchange rate should be allowed to float as freely as possible (Edwards, 2006). Capital controls are considered inappropriate, and reserve accumulation limited to the minimum necessary to curtail excessive volatility associated with non-fundamental shocks. Implicit is the presumption that exchange rate movements are not destabilizing, and in particular depreciations are assumed to be expansionary both in the long- and in the short-run (see Chang, 2008, for a discussion).

In the Structuralist literature, it was often assumed that devaluations have contractionary effects, at least in the short-run (Krugman and Taylor, 1978; Heymann and Nakab, 2017). The contractionary devaluation hypothesis was formalized during the 1950s and 1960s and the main mechanism is the redistributive effect (Diaz Alejandro, 1963, 1965). When price elasticities in consumption and production are low (Hansen, 1983), a devaluation has a strong income effect and almost no substitution effect. If the supply of tradable goods is given and if domestic goods required imported inputs in fixed proportion (Schmid, 1982; Gylfason and Risager, 1984), an increase in the nominal exchange rate will reduce the real wage, increasing profits and rents. If workers have a larger propensity to spend than capitalists and landlords, demand for home goods will fall.

Contractionary effects of devaluations can take place even if there is no redistributive effect. For example, output and employment will fall if the trade balance is initially in deficit (Robinson, 1947; Hirschman, 1949). If the public sector collects taxes on exports and tariffs on imports, then a devaluation will redistribute income from the private sector to the public sector; intuitively, the government has a marginal propensity to spend equal to zero, while the same figure for the private sector is presumably positive. The redistribution from the private sector to the public sector may reduce spending.

During the last 50 years the world has witnessed an important transformation of the international capital market. The collapse of Bretton Woods and the emergence of a system where capital moves more freely across borders has influenced the way the prices of financial assets are determined. Exchange rates have become much more volatile, and this may have disturbing effects on output and employment. The contractionary effects associated with financial distress linked to currency mismatches are related to the so-called "balance sheet effect". This channel can account for the same effects postulated by the old literature, but it can also explain modern financial crises in emerging and less developed economies. Céspedes et. al., (2003) offered a plausible formalization of this effect using a standard IS-LM-BP model. They endogenized the risk premium and showed that a depreciation of the domestic currency could be expansionary o contractionary, depending on the level of indebtedness and the foreign trade elasticities, among other things. Rojas-Suarez (1987) built a model where a devaluation tightens financial conditions for firms, reducing output and employment in the tradable and the non-tradable 
sector. Libman (2019) explored the role of the balance sheet when the central bank targets inflation using an interest rate rule, and he found that contractionary depreciations can create instability.

It is also important to consider the differences between the effects of changes vs. levels of the real exchange rate on macroeconomic variables. ${ }^{4}$ Even if exchange rate depreciations have short-run contractionary effects, some authors consider than an undervalued exchange rate can favour growth in the long-run. For example, Rodrik (2008) finds a positive relationship between real exchange rate level and growth, which is stronger for developing than developed countries. Likewise, Missio et al., (2015), using a quantile regression method, find this positive relationship to be non-linear but quadratic for developing countries. Oreiro et al. (2020) explain this relationship by the long-term positive impact of exchange rate level on manufacturing share and exports, while Gabriel et al., (2020) add that this relationship is greater the larger the country's gap in relation to the technological frontier.

The empirical literature on contractionary effects of devaluations is vast, but the findings are mixed. For instance, Bebczuk et al. (2006) found that devaluations are contractionary on highly dollarized economies, but expansionary otherwise, while other studies suggest that devaluations are short-run contractionary, but expansionary or "neutral" when the span of time considered is long enough (Edwards, 1986; Kamin and Klau, 1997).

As some studies have shown, it is difficult to disentangle the effects of devaluations from some other shocks that can affect the exchange rate and output at the same time (Edwards, 1989; and Kamin, 1988). Using different samples and including a different type of episodes may also affect the results. For example, Gylfason and Schmid (1983), and Gylfason and Radetzki (1991) found that devaluations are contractionary in the short and in the medium run using macroeconomic simulation for 10 and 12 less developed countries, respectively. Bahmani-Oskooee (1998) showed that devaluations have no long-run effect on output in most less developed economies.

Galindo et al. (2003) provided a survey of empirical studies on the impact of exchange rate fluctuations on economic activity and investment when currency mismatches are present. Microeconomic evidence suggests that Latin American firms tend to match the composition of their debt with the currency composition of their income stream, in particular if a more flexible exchange rate regime is adopted (Martínez and Werner, 2002). ${ }^{5}$

Bahmani-Oskooee and Miteza (2003) concluded that the impact is country

\footnotetext{
${ }^{4}$ We are grateful to one of the anonymous referees for suggesting that we make this difference clearer. Without necessarily supporting any particular view, we should notice that according to our empirical results, an exchange rate shock leads to a contraction in output that is statistically significant for 2 quarters, although we do not find any positive effect afterwards.

${ }^{5}$ The literature that explores firm level investment is vast, and the results are mixed. For example, Serena and Sousa (2018), Aguiar (2005), Carranza et al. (2003) found that depreciations reduce output, but Benavente et al. (2003), Bleakley and Cowan (2002), Bonomo et al. (2003), Domac (1997), Echeverry
} 
specific, depends on model specification and the on the estimation technique. Because it seems likely that the signs of the effect may depend on the country, the results change according to the cases included. Many studies have focused on Latin America. Using Lucas-type supply function, Sheey (1986) pooled cross-country data for countries from the region to estimate the impact on short-run output growth of devaluations (among other shocks). The results strongly support to the contractionary impact of devaluation.

Morley (1992) analyzed the effect of real exchange rates on output during 28 devaluations in developing countries, holding constant the terms of trade, import growth, the money supply and the fiscal balance. He found that depreciations of the real exchange rate reduce output over a period of two years, but does not test to see whether this effect is subsequently reversed. An et al. (2014) studied VAR models, including countries from Latin America and Asia, and they found supporting evidence for the presence of contractionary effects of devaluations.

Amhed (2003) studied the sources of economic fluctuations in key Latin American countries. Surprisingly, he found that external shocks play a limited role in driving output fluctuations in these countries. However, there is some evidence that real exchange rates depreciate in response to adverse external shocks and this depreciation tends to contract output in the short run. Gutiérrez de Piñeres and Cantavella-Jordá (2010) used pooled time series of Latin America countries, and they find that depreciations do not lead to faster export growth. This increases the likelihood of contractionary effects of depreciation. ${ }^{6}$

The effects of exchange rate fluctuations on output may depend not only on the country or the region, but also on the size of the depreciation. Berganza et al. (2004) showed that in times of crisis, when large depreciations usually take place, the effects on the balance sheets are stronger than during "normal" times. Because an exchange rate depreciation will reduce the value of the collateral in dollars, and as discussed in the empirical contribution of Mantey (2013) or in Kearns and Patel (2016), the effects of the real exchange rate on balance sheet may off-set the competitiveness effect (the positive effect on net exports).

The results could also depend on the time frame and the dynamics may involve short-run contractionary effects with long-run positive effects. Bussiáre et al. (2010)

et al. (2003), Galiani et al. (2003) found the opposite. There seems to be no disagreement on one particular point: the balance sheet effect is important.

${ }^{6}$ Several studies have analyzed the nature of depreciations in Asia. Christopolous (2004) studied eleven Asian economies using panel cointegration techniques, and he finds that depreciations are contractionary in the long run at least in five of them, and expansionary in three. Bahmani-Oskooee et al. (2002) studied the East Asian case. They estimated a cointegration vector that relates output with the real exchange rate and other policy variables, using quarterly data for 1976-1999. They find that although real depreciation is contractionary in the long run for Indonesia and Malaysia, it is expansionary for the Philippines and Thailand. For Korea, output growth does not significantly respond to a change in the real value of the exchange rate. Likewise, Moreno (1999) finds that real depreciation dampens economic activity for a panel of East Asian economies. Kim (2016) showed that the balance sheet effect is relevant in a panel of South Korean firms. 
explored episodes of "Currency collapses", defined as large nominal depreciations or devaluations. They find that they are associated with permanent output losses on the order of $6 \%$ of GDP, on average. However, these losses tend to materialize before a drop in the value of the currency, which indicates that it is not the large depreciation as such that is costly but the factors leading to the currency collapse. Rajan and Shen (2006) showed that depreciations have contractionary effects during crisis periods, but not during normal times.

The question about the effects of depreciations on output is old, but surprisingly, there are little updated contributions that analyze countries that use Inflation Targeting; as the literature review illustrates. We thus contribute to the literature on Inflation Targeting on open economies and to the literature on contractionary effects of devaluation, by analyzing the five Latin American countries that have been using Inflation Targeting for almost two decades. We provide empirical estimations based on VAR models and we offer new theoretical insights about the possible destabilizing effects of devaluations when a standard Taylor Rule is operative.

This paper is also related to Post-Keynesians monetary theory. Authors from the Post-Keynesian tradition, most remarkably those who seem to embrace an "activist" view (those who agree that a short-term interest rate can be used to stabilize the economy, provided that it is complemented with other policies), have analyzed the Inflation Targeting regime in a closed economy set-up, and they show that full-employment and price stability can be achieved combining the Taylor Rule with an additional instrument (Tadeu-Lima and Setterfield, 2008). But none of these papers have addressed the complications associated with contractionary effects of devaluations.

\section{EMPIRICAL RESULTS}

In this section we construct a series of Vector Autoregressive models for the five most important Latin American countries that have been using Inflation Targeting for almost two decades (Brazil, Chile, Colombia, Mexico, and Peru). We focus on the effects of exchange rate shocks on output and the consumer price index spanning the late 1990s or the early 2000s (see Table 1) and 2019, but the remaining of the results are available on request. The dataset used in this paper comprises quarterly data of key domestic and international macroeconomic variables. All data were publicly available and provided by official national statistical offices or official data repositories. The set of domestic variables are the Gross Domestic Product (GDP), the key monetary policy interest rate set by the Central Bank (I), the exchange rate (ER), and the Consumer Price Index (CPI).

The dataset also covers international variables that would make economic sense to control for. This set of variables comprises a variety of international prices of commodities provided by the World Bank's Pink Sheet, the Federal Funds Rate (FFR) and the CBOE Volatility Index (VIX), both made available by the Federal 
Reserve Economic Data (FRED). The time span of the dataset matches that of the Inflation Targeting regime for each of the countries.

We estimated an individual Vector Autorregresive (VAR) model with exogenous variables for each country. We choose this approach because it is reasonable to assume interactions between the endogenous (domestic) variables and because it gives us the opportunity to check how exchange rate shocks may affect the GDP under different specifications. A VAR model of order $p$ with exogenous variables can be written as:

$$
Y_{t}=C+A_{1} Y_{t-1}+\cdots+A_{p} Y_{t-p}+B X_{t}+\varepsilon_{t},
$$

where $Y_{t}$ is a vector of endogenous variables, the $A_{j}$ 's are $\mathrm{k} \mathrm{x} \mathrm{k} \mathrm{coefficient} \mathrm{ma-}$ trices, $B$ is a $\mathrm{k} \mathrm{x} \mathrm{m}$ coefficient vector, $\mathrm{C}$ is a vector of intercepts, and $\varepsilon_{t}$ is the vector of errors.

Before the estimation of the model, we tested for the order of integration for each variable after taking logarithms (except for interest rates). We used ADF tests and relied on KPSS test when necessary, concluding that all log series are integrated of first order and proceeded to differentiate each one to make them stationary (see Table A.1 for the results of the tests). We chose the optimum lag for each VAR model based on BIC, adding new lags if errors presented signs of residuals autocorrelation or heteroscedasticity (see Table 1).

Table 1: Data Sample and VAR Models Lags

\begin{tabular}{lcc}
\hline \multicolumn{1}{c}{ Country } & Time span & Lags \\
\hline Brazil & $199902-201904$ & 3 \\
Chile & $199601-201904$ & 2 \\
Colombia & $2000 \mathrm{Q} 1-201904$ & 2 \\
Mexico & $200402-201904$ & 2 \\
Peru & $200304-201904$ & 2 \\
\hline
\end{tabular}

Source: Authors' own elaboration.

It is known that the correlations between each individual error are rarely equal to zero. An orthogonalization of the error terms is needed to identify what is known as structural shocks or innovations. We use the standard Cholesky decomposition of the covariance matrix. On the Appendix, which is in the on-line version of this journal, we show the Impulse Response Function (IRF) for each of the 24 possible Cholesky orderings per country to show that broad conclusions do not rely on a specific ordering (Figures A.1 and A.2). Next, we focus on an ordering that we think that make economic sense and show IRF as well as the Forecast Error Variance Decomposition (FEVD) analysis to account for the magnitude of the impact of devaluation on the GDP.

The results show that the effect is contractionary in the short-run, for about 1 to 4 periods, and up to 7 for the case of Brazil. The effects are statically significant for Brazil and Mexico for 2 to 4 quarters, but not in the rest of countries, although 
we should keep in mind that the models have very few degrees of freedom due to our restricted sample and 2 or 3 lags per each variable (see Figure 1). This is not necessarily a limitation of our model. In fact, it is consistent with some of facts discussed in the introduction which suggests that contractionary effects were present in Brazil and Mexico.

Figure 2 shows the percentage of the Forecast Error Variance Decomposition of the GDP that is explained by a shock to the exchange rate. In Mexico and Brazil, a shock to the exchange rate explains approximately $15 \%$ of the total variance of the GDP, while its impact is reduced to $7.5 \%$ in Peru and is even lower in Chile and Colombia.

Figure 3 shows the effect of an exchange rate shock on the CPI in the short-run. The effects are usually mildly inflationary and almost always die-out after 4 quarters, and the coefficients are usually not significant, with the sole exception of Brazil and Colombia. Figure 4 shows the percentage of the Forecast Error Variance Decomposition of the CPI that is explained by a shock to the exchange rate. The picture clearly shows a large contribution (more than $30 \%$ ) for Brazil, and below $10 \%$ for the other four cases.

To summarize, our baseline results suggest the presence of short-run contractionary effects of depreciations on output, particularly for Brazil and Mexico, and a somewhat weak effect on CPI, with the exception of Brazil. The results are strongly robust to the different 24 possible orderings.

Figure 1: Impulse Response Functions. Effects of Exchange Rate shocks on GDP. Cholesky ordering: Exchange Rate, GDP, Consumer Price Index, Interest Rate
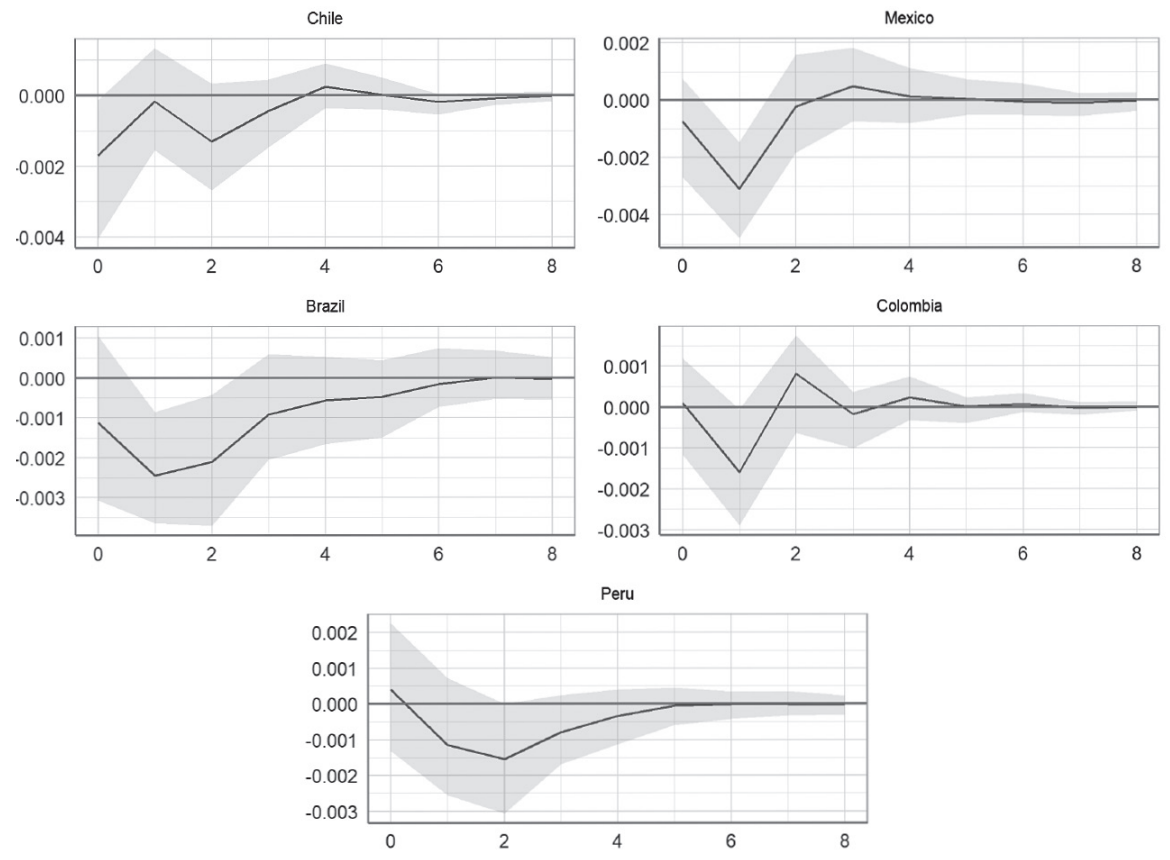

Source: Authors' own elaboration. 
Figure 2: Variance decompositions. Effects of Exchange Rate shocks on GDP. Cholesky ordering: Exchange Rate, GDP, Consumer Price Index, Interest Rate

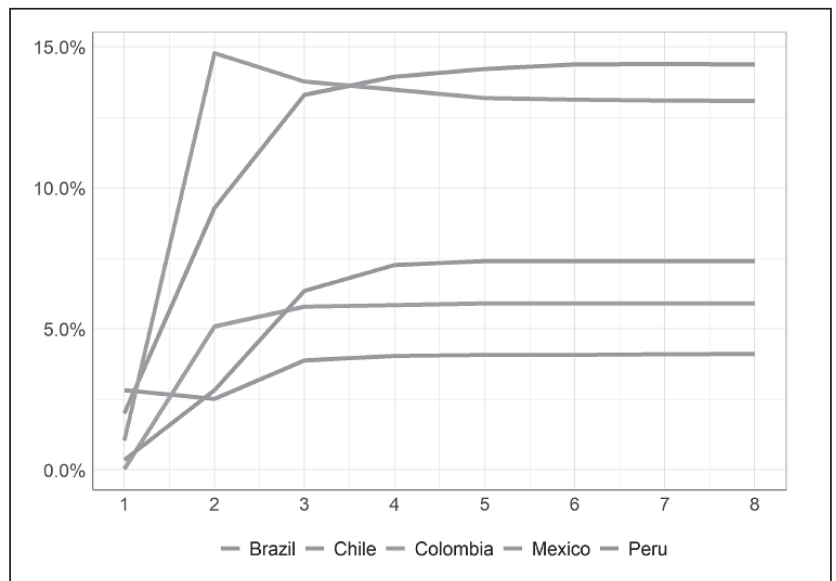

Source: Authors' own elaboration.

Figure 3: Impulse Response Functions. Effects of Exchange Rate shocks on Consumer Price Index. Cholesky ordering: Exchange Rate, GDP, Consumer Price Index, Interest rate

Chile

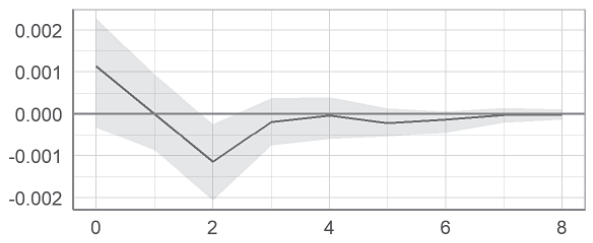

Brazil

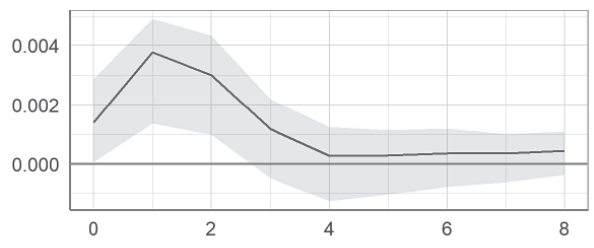

Mexico

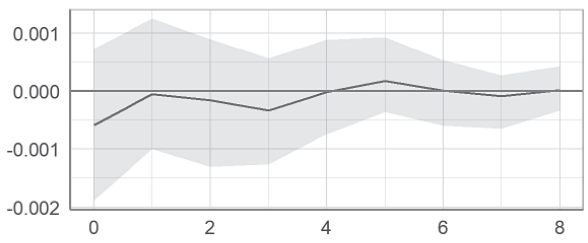

Colombia

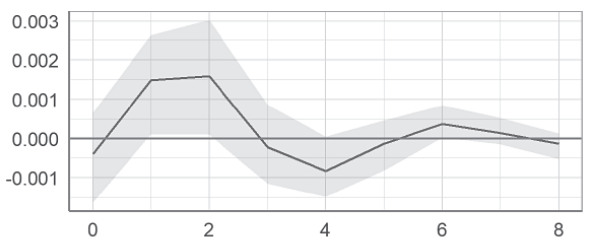

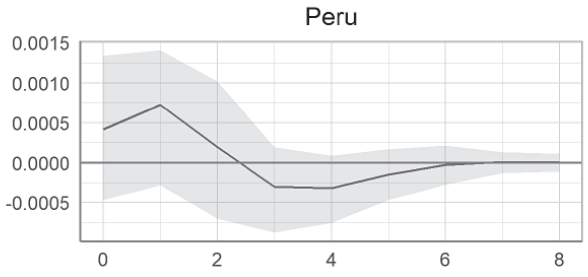

Source: Authors' own elaboration. 
Figure 4: Variance decompositions. Effects of Exchange Rate shocks on Consumer Price Index. Cholesky ordering: Exchange Rate, GDP, Consumer Price Index, Interest rate

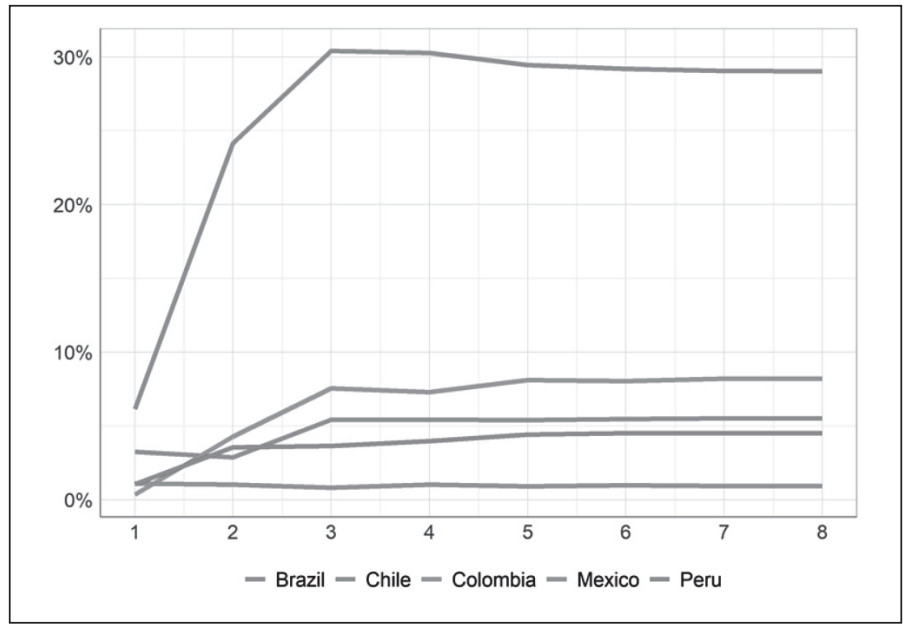

Source: Authors' own elaboration.

\section{A TOY MODEL}

This section develops the basic framework to present the main implications for monetary policy when depreciations have contractionary effects on output. We show that the stability conditions are less stringent when depreciations are also inflationary, but this also implies that policies that delink the evolution of the exchange rate from the interest rate can be stabilizing or even that a policy that parks the interest rate may be a better approach than a standard Taylor Rule (Libman, $2018 \mathrm{~b}$ ). The main take home point of our model is that the presence of contractionary effects of depreciations may add undesirable destabilizing effects when the capital account is very open and monetary policy is conducted targeting a short-term interest rate. This lesson is consistent with the recent experience of Brazil and Mexico, the two cases where Inflation Targeting have been associated with sluggish growth, volatile inflation and higher exchange rate volatility (see Libman, 2020).

Our specification is designed to resemble as much as possible the standard New Consensus Model for an open economy, for comparison purposes. The model has three main elements. The first one is the dynamic equation for inflation and output. This rate of inflation depends on the gap between the target real wage and the actual real wage. The target real wage, in turn, depends on the state of the labor market and on the real exchange rate; those variables capture the influence of the bargaining power of workers and the cost of living, which following the structuralist literature, is positively associated with the level of the real exchange rate. Finally, we assume that the rate of employment depends on the level of output, which 
is a function of the real interest rate, the real exchange rate, and some other factors. Those variables capture the traditional income and substitution effect, and the signs can be influenced by the effects of depreciations on income distribution. Put it differently, contractionary effects of depreciations associated to the redistributive effect of Diaz Alejandro is implicit in the specification if the real exchange rate enters with a negative sign on the aggregate demand function.

Secondly, we assume an extremely open capital account plus high substitutability between domestic and foreign assets. This is clearly an unrealistic approach (see Zhou, 2002), but it does not affect the main goal of the model. For our purposes, any specification that involves a negative relation between interest rates and exchange rates will work. Thirdly, the domestic interest rate is set according to a standard Taylor Rule, which is a typical feature of Inflation Targeting, and thus the short-term interest rate is a positive function of the inflation and output gaps.

Unless otherwise noticed, all the variables except for nominal and real interest rates are expressed in natural logs. To keep the notation simple, we omit the time subscripts, except when otherwise noticed. The price level of domestically produced goods $p$ is equal to a markup $m$ over wage costs $w:^{7}$

$$
p=m+w
$$

Differentiating (2) with respect to time and assuming a constant markup, the rate of inflation is equal to the rate of growth of wages $\pi=\dot{w} .{ }^{8}$ Wages evolve as a function of past inflation $\pi_{-1}$ and the gap between the target real wage $\omega^{T}$ and the observed real wage $\omega$ :

$$
\dot{W}=\pi_{-1}+\beta\left(\omega^{T}-\omega\right) \text { with } \beta>0
$$

Notice that $\dot{\pi} \approx \pi-\pi_{-1}$ so according to (3) the rate of change of inflation depends on the "wage gap" $\omega^{T}-\omega$. Implicit is the assumption that expected inflation $\omega^{e}$ is equal to past inflation $\pi_{-1}$. A more realistic approach would probably imply that wages are imperfectly indexed to inflation and a non-constant markup. Modifying the model along those lines only make the dynamics more complex and, importantly, make contractionary effects of depreciation a more likely outcome, reinforcing out conclusions: after a nominal depreciation the nominal wage and inflation will increase by less and the real exchange rate will increase by more. To simplify, we assumed that contemporary inflation is fully indexed to past inflation and that the effect of the interest rate on the markup is negligible 9 .

\footnotetext{
${ }^{7}$ Thus, the price level is equal to one plus the markup times the level of the nominal wage. In other words, $P=(1+m) W$. Then $p=\ln (P), w=\ln (W)$ and $m \approx \ln (1+M)$.

${ }^{8}$ We denote by $\dot{a}$ the derivative of $a$ with respect to time.

${ }^{9}$ As suggested by an anonymous referee, it is more appropriate to let the markup to be endogenously determined, for example, by assuming that the markup depends positively on the level of the interest rates. We choose to retain the assumption that the markup is given in order to work with a relatively simple model that resembles it as much as possible the standard New Consensus framework. On the
} 
The observed real wage is defined as the ratio between the nominal wage and the domestic consumer price index, which includes domestic and foreign components: ${ }^{10}$

$$
\omega=\frac{W}{C P I}=w-c p i=w-a p-b E \text { with } a, b>0 \text { and } a+b=1
$$

where $E$ is the nominal exchange rate and also the price of imported goods (for simplicity, we assume that the law of one price holds, and that foreign price is constant and equal to one). Notice that using (2), it follows that $w=p-m=a p+b E-m$, so we can rewrite (4) as follows:

$$
\omega=p-m-a p-b E=-b Q-m
$$

where $Q=E-p$ is the real exchange rate. According to (5) the real wage is a negative function of the real exchange rate and the markup. We adopt a linear specification for $\omega^{T}$, and we include the level of employment as the main determinant. Higher (lower) levels of employment tend to increase (decrease) bargaining power, so the target real wage tends to increase (decrease).

Employment is defined by aggregate demand, which depends on the real exchange rate, the real interest rate, and other factors. More precisely:

$$
\dot{u}=\delta\left[u_{0}-u_{1}(i-\pi)-u_{2} Q-u\right] \text { with } u_{1}, u_{2}, \delta>0
$$

Equation (6) says that capacity utilization tends to increase (decrease) when demand is above (below) the current level of capacity utilization. The new term $i$ is the domestic nominal interest rate so $i-\pi$ is the real interest rate. Notice that we assume that depreciations have short-run contractionary effects on output and employment, and thus a higher (lower) $Q$ cuts (expands) demand. The sign $\mathrm{u}_{2}>0$ can be justified by any of the channels discussed in the literature review and it is similar to the assumption that the economy is wage-lead. ${ }^{11}$

As discussed previously, the target real wage is an increasing function of employment, ${ }^{12}$ which depends positively on capacity utilization:

$$
\omega^{T}=\rho_{0}+\rho_{1} u \text { with } \rho_{1}>0
$$

empirical grounds the effects of interest rates on the price level is weak, and our own estimations (available on request), confirm this except for the case of Brazil.

${ }^{10}$ The consumer price index is defined as $C P I=P^{a} S^{b}$, where $P$ and $S$ are the price of domestic and foreign goods, with weights $a$ and $b$ (and $b+a=1$ ). Taking logs, we obtain $c p i=a p+b E$, assuming $c p i=$ $\ln (C P I), p=\ln (P)$ and $E=\ln (S)$.

${ }^{11}$ In our set-up, the real wage varies inversely with the real exchange rate: unless we allow for additional shocks, such as changes in the markup, the real wage cannot increase if the real exchange rate goes up. Expansionary depreciations can be captured by setting $u_{2}<0$. The data for Latin America usually shows that a higher (lower) real exchange rate is associated with a lower (higher) real wage (see for instance Gerchunoff and Rapetti, 2016, for the Argentinean case).

${ }^{12}$ Implicit in our price equation (2) there is a production function with fixed proportion, so employment and output vary in the same direction and proportion. If we let employment, output to labor ratio, and the capital to labor ratio to be denoted by $N, a$ and $k$, then $N=a u k$. 
Combining (3), (5), and (7) we obtain an expectations augmented Phillips Curve:

$$
\dot{\pi}=\beta\left(\rho_{0}+\rho_{1} u+b Q+m\right)
$$

To model the balance of payments and the exchange rate, we assume that a modified version of the uncovered interest parity holds, following a slight modification of the framework proposed by Oreiro and Guerbberoff (2006). Thus:

$$
e^{e}=(1-k)\left(i-i^{*}\right)
$$

where $i^{*}$ is the nominal foreign interest rate and $e^{e}$ is the expected rate of depreciation. To simplify the notation, we set $i^{*}=0$. The term $0 \leq k \leq 1$ measures the level of capital controls. According to (9), a higher (lower) $k$ reduces (increases) the impact of a given interest rate differential on the expected rate of depreciation. We assume that expectations follow a regressive pattern, and thus the expected rate of depreciation obeys:

$$
e^{e}=x(\bar{Q}-Q) \text { with } x>0
$$

where $\bar{Q}$ is the long-run real exchange rate. Combining (9) and (10) we obtain:

$$
Q=-\alpha i \text { with } \alpha=\frac{1-k}{x}>0
$$

To simplify, we have set the equilibrium real exchange rate equal to one, which implies $\bar{Q}=C$ because the variables are defined in logs. In the present set-up, this equilibrium real exchange rate can be computed by setting capacity utilization equal to its long-run level $\bar{u}$ into equation (6), and then solving for $Q$ in (5). ${ }^{13}$

Finally, the nominal interest rate is adjusted according to a standard Taylor Rule. We assume that the central bank adjusts the rate as a function of its deviations from its optimal level, which is a function of the inflation and the deviation of capacity utilization from its long run equilibrium $\bar{u}$ :

$$
i=\bar{\pi}+\theta_{1}(\pi-\bar{\pi})+\theta_{2}(u-\bar{u})+i^{*}-\pi^{*} \text { with } \theta_{1}, \theta_{2}>0
$$

Where the optimal rate is equal to domestic inflation plus two terms that are increasing in the deviation of inflation from the target $\bar{\pi}$ (which is also the steady state) and the output gap. Notice that we set $i^{*}=0$ and $\pi^{*}=0$. We included these terms in the equation (12) as a reminder that in equilibrium $\pi=\bar{\pi}$ and $\mathrm{u}=\bar{\pi}$, so the optimal rate minus the target rate of inflation $\bar{l}-\bar{\pi}$ should be equal to foreign real interest rate (because we assumed perfect capital mobility).

\footnotetext{
${ }^{13}$ Notice that due to perfect capital mobility, the sign of the current account is irrelevant in the shortrun, and we can fully depict the macroeconomic equilibrium without it. In other words, any current account deficit or surplus can be covered by capital inflows or outflows. This is not a bad assumption for Latin American countries during the 2000s and the early 2010s. As they experienced large balance of payments surplus, presumably the implicit equilibrium real exchange rate $\bar{Q}$ is not inconsistent with external disequilibrium. We omit current account dynamics for our story to keep the model as simple as possible. We should also notice that, as discussed by Gerchunoff and Rapetti (2016), the level of the real exchange rate that is consistent with external equilibrium may not coincide with the level of the real exchange rate that is consistent with workers and firm's aspirations. We also omit such complication to focus on the destabilizing effects that are the main theme of the model.
} 
The model can be reduced to a $2 \times 2$ system of differential equation on $\pi$ and $u$, by combining (8) with (11) and (12), and equations (6) with (11) and (12). More precisely, notice that if we subtract inflation $\bar{\pi}$ from both sides, we can write the Taylor Rule as follows:

$$
i-\pi=\left(\theta_{1}-1\right)(\pi-\bar{\pi})+\theta_{2}(u-\bar{u})
$$

On the other hand, if we combine the equation for the real exchange (11) with the Taylor Rule (13):

$$
Q=-\alpha\left[\bar{\pi}+\theta_{1}(\pi-\bar{\pi})+\theta_{2}(u-\bar{u})\right]
$$

Equation (13) should be inserted into (6), while (13) and (14) should be inserted into (8), to obtain:

$$
\begin{aligned}
& \dot{\pi}=\beta\left\{\rho_{0}+\rho_{1} u-\alpha b\left[\bar{\pi}+\theta_{1}(\pi-\bar{\pi})+\theta_{2}(u-\bar{u})\right]+m\right\} \\
& \dot{u}=\delta\left\{u_{0}-u_{1}\left[\left(\theta_{1}-1\right)(\pi-\bar{\pi})+\theta_{2}(u-\bar{u})\right]+u_{2} \alpha\left[\bar{\pi}+\theta_{1}(\pi-\bar{\pi})+\theta_{2}(u-\bar{u})\right]-u\right\}
\end{aligned}
$$

This $2 \times 2$ system has a steady state where the output gap is zero, inflation is equal to the target, the domestic real interest rate is equal to the international rate, the rate of depreciation is equal to domestic inflation (so the real exchange rate is constant) and the real wage is equal to the target real wage. The Jacobean of (15)(16) evaluated at the steady-state is given by:

$$
J=\left|\begin{array}{ll}
A 11 & A 12 \\
A 21 & A 22
\end{array}\right|=\left|\begin{array}{cc}
-\beta \alpha b \theta_{1} & \beta\left(\rho_{1}-\alpha b \theta_{2}\right) \\
\delta\left[u_{1}\left(\theta_{1}-1\right)+u_{2} \alpha \theta_{1}\right] & \delta\left[\theta_{2}\left(u_{2} \alpha-u_{1}\right)-1\right]
\end{array}\right|
$$

Notice that all the terms are ambiguous except for A11. All of them depend on the effects of devaluations on output and inflation, and on the behavior of the central bank. It is still possible to obtain interesting insights. Notice that if the Taylor Principle holds, then it is natural to set $\theta_{1}>1$ so the nominal interest rate tends to increase by more than inflation when there is excess demand for goods. Keeping that in mind, it follows that the sign of $A 12, A 21, A 22$ depends on whether a higher real interest rate, which leads to a real exchange rate appreciation, expands or cuts aggregate demand (which depends on the sign of $\alpha u_{2}-u_{1}$ ), and on how strongly does the central bank targets output (captured by the term $\theta_{2}$ ).

Setting $\dot{\pi}=0$ and $\dot{u}=0$, the isoclines relative to equations (15) and (16) are respectively:

$$
\begin{aligned}
& \frac{d \pi}{d u}=\frac{-\rho_{1}+\alpha b \theta_{2}}{-\alpha b \theta_{1}} \\
& \frac{d \pi}{d u}=\frac{\theta_{2}\left(u_{1}-u_{2} \alpha\right)-1}{-u_{1}\left(\theta_{1}-1\right)-u_{2} \alpha \theta_{1}}
\end{aligned}
$$

Notice that the slopes represented in (18) and (19) can have any sign. Intuitively, the stable case resembles the standard aggregate demand - aggregate supply model with the "correct" slopes. The unstable cases are associated with an aggregate supply curve and an aggregate demand curve which are downward and upward slopped, respectively. Intuitively, the aggregate supply curve can be downward slopped if high output leads to a strong increase in the real interest rate, which triggers a real exchange 
rate appreciation; if the effect of the exchange rate on prices is very strong, inflation falls. In the same vein, the aggregate demand curve can be upward slopped if higher inflation leads to a higher real interest rate, which creates pressures towards real exchange rate appreciation. When depreciations are strongly contractionary appreciations are expansionary, so output will tend to increase in order to restore the balance in the goods market. Figures 5, 6 and 7 show the stable $(T R<0$ and DET $>0)$ and two unstable cases $(T R<0$ and $D E T<0)$, which corresponds to the case where the aggregate supply and the aggregate demand curve have the wrong slope, respectively.

Figure 5: Dynamic Behavior (Stable Case)

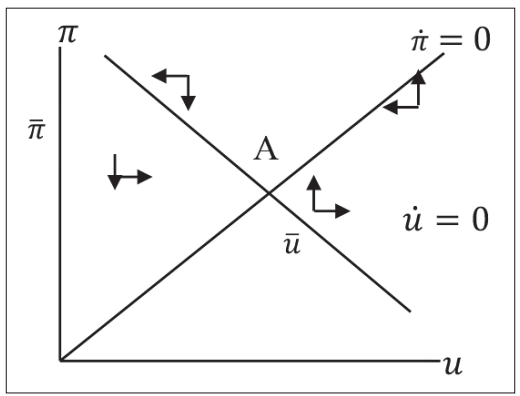

Source: Author's own elaboration.

Figure 6: Dynamic Behavior (Unstable case I)

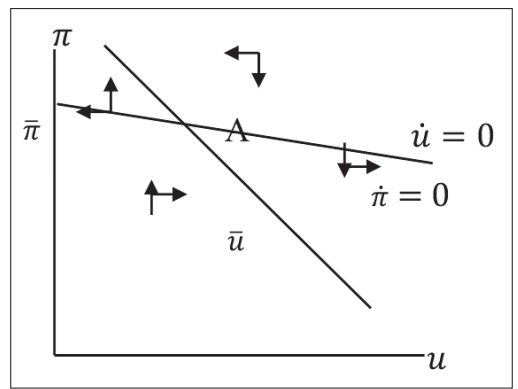

Source: Author's own elaboration.

Figure 7: Dynamic Behavior (Unstable case II)

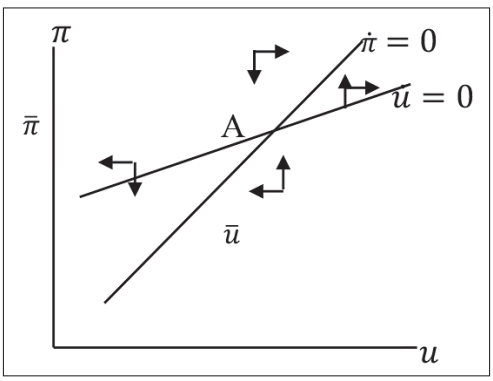

Source: Author's own elaboration. 
In order to get additional intuitions, let us focus on the case where the central bank does not target output, so $\theta_{2}=0$, which simplifies the analysis. The trace and the determinant of (17) satisfy:

$$
\begin{aligned}
& T R=-\beta \alpha b \theta_{1}-\delta \\
& D E T=\beta \alpha b \theta_{1} \delta-\delta\left[u_{1}\left(\theta_{1}-1\right)+u_{2} \alpha \theta_{1}\right] \beta \rho_{1}
\end{aligned}
$$

It follows that a sufficient condition for stability is that the Determinant is positive. This is always true if the effects of monetary policy on output through its effect on the real exchange rate (captured by $\alpha u_{2}$ ) are relatively weak (or when depreciations are expansionary $u_{2}<0$, which is the only case were a parameter can have a negative sign in our model) and if the central bank does not react to strongly to changes in inflation $\theta_{1}<1$. Strongly contractionary effects of depreciation can thus be destabilizing, even if the central bank follows the Taylor Principle $\left(\theta_{1}>0\right)$. A sensible option to avoid instability is to minimize the effects of interest rate policy on the real exchange rate. Specifically, consider equation (11), which can we written as follows $Q=-\left(\frac{1-k}{x}\right) i$. If. If the sensibility of the real exchange rate with respect to changes in nominal interest rate $\alpha$ is small (which means that $k$ is high), the effects of devaluations on output are also small and stability becomes more likely. We can thus consider sales and purchases of foreign assets (which increase $x$ ) and some forms of capital controls (an increase in $k$ ) as policy option to prevent some of the destabilizing dynamics described above.

Returning to the general case where $\theta_{2}>0$, with large contractionary effects of depreciations, now it is possible to obtain $A 22>0$. This is enough to create a system with one or two positive roots, which is unstable or there exists only one path that converges to equilibrium. But even when $A 22<0$, there could also be only one trajectory that converges if the cross terms $A 21$ and $A 12$ have the same sign. This can happen if depreciations are contractionary and if the pass-through from exchange rate to prices is low. Expansionary depreciations with very high pass-through will have the similar effect.

The implication that the system may not be stable should not be taken literally, but it suggests that using a standard Taylor Rule may increase the volatility of inflation and output, and the presence of strong contractionary effects of depreciations are an additional source of concern. In the best performing cases, this problem was address by the utilization of unconventional macroeconomic policies that limited the destabilizing effects of large exchange rate fluctuations.

\section{CONCLUSIONS}

In this paper we have discussed the implications of contractionary depreciations for an economy that targets inflation and manages monetary policy following a 
standard Taylor Rule. On the empirical front, we focused on the five most important Latin American countries that have been using Inflation Targeting for almost two decades, namely Brazil, Chile, Colombia, Mexico, and Peru. Exploring the data from the recent period, we constructed a series of VAR models and we showed that devaluations are contractionary in the short-run in Brazil and Mexico (and inflationary in Brazil).

These findings have important implications for the design of an optimal monetary policy. We have shown this by building a stylized model where devaluations are both contractionary and inflationary, and were instability cannot be ruled out. It is thus not surprising that many central banks adopted unconventional policies to complement the Taylor Rule, and that central banks do not change the target interest rate very often, or they do it cautiously and with important lags.

Related to the model and the empirical results, Brazil and Mexico, performed much worse than Chile, Colombia and Peru in terms of growth and inflation (see Libman, 2020). These differences in performance can be attributed, presumably among other things, to the failure to adopt policies that take into account the presence of contractionary effects, or simply to the fact that these contractionary effects were strong and/or Brazil and Mexico suffered from large exchange rate shocks.

The main lessons of this paper are thus twofold. First, unconventional monetary policies, which are increasingly recognized as a useful complement to the administration of the interest rate, may be required to fully stabilize an open economy that adopts Inflation Targeting. Second, the calibration of macroeconomic policies requires to take the contractionary effects of depreciations seriously.

\section{REFERENCES}

Amhed, S. (2003). Sources of economic fluctuations in Latin America and implications for choice of exchange rate regimes, Journal of Development Economics, vol. 72, no. 1, 181-202.

An, L., Kim, G., and Ren, X. (2014). Is devaluation expansionary or contractionary: Evidence based on vector autoregression with sign restrictions, Journal of Asian Economics, vol. 34, no. C, 27-41.

Bahmani-Oskooee, M. (1998). "Are Devaluations Contractionary in LDCs? Journal of Economic Development”, vol. 23, no. 1, 131-144.

Bahmani-Oskooee, M., and Mitez, I. 2003. Are Devaluations Expansionary or Contractionary? Economic Issues, 8 no. 2, 1-28.

Bahmani-Oskooee, M., Chomsisengphet, S., and Kandil, M. (2002). Are Devaluations Contractionary in Asia? Journal of Post-Keynesian Economics, vol. 25, no. 1, 69-82.

Bebczuk, R., Galindo, J., and Panizza, U. (2006). An Evaluation of the Contractionary Devaluation Hypothesis, IDB Working Paper No. 486.

Blanchard, O., and Galí, J. (2007). Real Wage Rigidites and the New Keynesian Model, Journal of Money, Credit, and Banking, vol. 39, no. 1, 35-65.

Bresser-Pereira, L. (2012). Structuralist macroeconomics and the new developmentalism, Brazilian Journal of Political Economy, vol. 32, no. 3, 347-366.

Bresser-Pereira, L. (2013). The value of the exchange rate and the Dutch disease, Brazilian Journal of Political Economy, vol. 33, no. 3, 371-387. 
Bussiére, M., Saxena, S., and Tovar, C. (2010). Chronicle of Currency Collapses: Re-Examining the Effects on Output, Journal of International Money and Finance, vol. 31, no. 4, 680-708.

Céspedes, L., Chang, R., and Velasco, A. (2000). Balance Sheets and Exchange Rate Policy, NBER Working Paper No. 7840.

Chang, R. (2008). Inflation Targeting, Reserves Accumulation, and Exchange Rate Management in Latin America, Borradores de Economía No. 487, Banco de la República, Colombia.

Christopolous, D. (2004). Currency devaluation and output growth: new evidence from panel data analysis", Applied Economic Letters, vol. 11, no. 13, 809-813.

Díaz-Alejandro, C. (1963). A Note on the Impact of Devaluation and the Redistributive Effect, The Journal of Political Economy, vol. 71, no. 6, 577-580.

Díaz-Alejandro, C. (1965). Exchange Rate Devaluation in a Semi-Industrialized Country. Cambridge, MA: MIT Press.

Edwards, S. (1986). Are Devaluations Contractionary? The Review of Economics and Statistics, vol. 68 no. 3, 501-508.

Edwards, S. (1989). Real Exchange Rates, Devaluation, and Adjustment Exchange Rate Policy in Developing Countries. Cambridge, MA. The MIT Press.

Edwards, S. (2006). The Relationship Between Exchange Rates and Inflation Targeting Revisited, NBER Working Paper no. 12163.

Gabriel, L. F., Ribeiro, L. C. S., Jayme Jr, F. G., and Oreiro, J. L. (2020). Manufacturing, economic growth, and real exchange rate: Empirical evidence in panel data and input-output multipliers. PSL Quarterly Review, vol. 73, no. 292, 51-75.

Galindo, L., and Ros, J. (2008). Alternatives to inflation targeting in Mexico, International Review of Applied Economics, vol. 22, no. 2, 201-214.

Gerchunoff, P. , and Rapetti, M. (2016). La economía argentina y su conflicto distributivo structural (1930-2015), El Trimestre Económico, vol. 83/2, no. 330, 225-272.

Gutiérrez de Piñeres, S., and Cantavella-Jordá, M. (2010). Short-run effects of devaluation: a disaggregated analysis of Latin American exports, Applied Economics, vol. 42, no. 2, 133-142.

Gylfason, T., and Radetzki, M. (1991). Does Devaluation Make Sense in Least Developed Countries? Economic Development and Cultural Change, vol. 40, no. 1, 1-25.

Gylfason, T., and Risager, O. (1984). Does devaluation improve the current account? European Economic Review, vol. 25, no. 1, 37-64.

Gylfason, T., and Schmid, M. (1983). Does Devaluation Cause Stagflation? The Canadian Journal of Economics, vol. 16, no. 4, 415-421.

Hanson, J. 1983. Contractionary Devaluation, Substitution in Production and Consumption, and the Role of the Labor Market, Journal of International Economics, vol. 14, no. 1-2, 179-189.

Heymann, D., and Nakab, A. (2017). Temas tradicionales. Sobre ciclos stop-go y devaluaciones contractivas. Desarrollo Económico, vol. 57, no 222, p. 203-229.

Hirschman, A. (1949). Devaluation and the Trade Balance: A Note, Review of Economics and Statistics, vol. 31, no. 1, 50-53.

Kamin, S. (1988). Devaluation, External Balance, and Macroeconomic Performance: A Look at The Numbers, Princeton Studies in International Economics, vol. 62.

Kamin, S., and Klau, M. (1997). Some Multi-Country Evidence on the Effects of Real Exchange Rates on Output, BIS Working Paper No. 48.

Kearns, J., and Patel, N. (2016). Does the Financial Channel of Exchange Rates Offset the Trade Channel? BIS Quarterly Review, 95-113.

Kim, Y. (2016). Foreign currency exposure and balance sheet effects: A firm-level analysis for Korea, Emerging Markets Review, vol. 26, no. C, 64-79.

Krugman, P. , and Taylor, L. (1978). Contractionary effects of devaluation. Journal of International Economics, vol. 8, pp. 445-56. 
Libman, E. (2018a). Inflation Targeting when Devaluations are Contractionary. The Review of Keynesian Economics, 6 no. 2: 180-201

Libman, E. (2018b). Asymmetric Monetary and Exchange Rate Policies in Latin American Countries that use Inflation Targeting CEPAL Review, 125, 29-46.

Libman, E. (2019) Inflation Targeting on a Financially Fragile Economy. Eastern Economic Journal., 2019, Vol. 45, 4, pp. 590-611.

Libman, E. (2020). A simple model of some possible long-run adverse effects of inflation targeting, Review of Social Economy, DOI: 10.1080/00346764.2020.1729995.

Mantey, G. (2013). ¿Conviene Flexibilizar el Tipo de Cambio para Mejorar la Competitividad? Revista Problemas del Desarrollo, vol. 175, no. 44, 9-32.

Missio F. J., Jayme Jr., F. G., Britto G., and Oreiro. J. L. (2015). Real exchange rate and economic growth: new empirical evidence, Metroeconomica, vol. 66, no. 4, 686-714.

Moreno, R. (1999). Depreciations and Recessions in East Asia, Federal Reserve Bank of San Francisco Economic Review, vol. 3, 27-40.

Morley, S. (1992). On the Effect of Devaluation During Stabilization Programs in LDCs. Review of Economics and Statistics, vol. 74, no. 1, 21-27.

Oreiro, J., and Da Agostini, L. (2017). Macroeconomic policy regimes, real exchange rate overvaluation, and performance of the Brazilian economy (2003-2015), Journal of Post-Keynesian Economics, vol. 40(1), 27-42.

Oreiro, J.L; De Paula, L.F. Sobreira, R. (2009). Politica Monetária, Bancos Centrais e Metas de Inflação: teoria e experiência brasileira. FGV Editora: Rio de Janeiro.

Oreiro, J., and Guerberoff, I. (2006). Endividamento Externo e Controles de Capitais: Uma análise computacional de um modelo macrodinâmico pós-keynesiano, Estudos Econômicos, vol. 36, no. 4, 747-777.

Oreiro, J. L., Martins da Silva, K., and Dávila-Fernandez, M. (2020). “A New Developmentalist Model of Structural Change, Economic Growth and Middle-Income Traps”. Structural Change and Economic Dynamics, Vol. 55, 26-38.

Oreiro, J., and Santana, B. (2018). Real exchange rate and structural change in a Kaldorian balance of payments constrained growth model, Brazilian Journal of Political Economy, vol. 38, no. 1, 4869.

Rajan, R., and Shen, C. (2006). Why Are Crisis-Induced Devaluations Contractionary? Exploring Alternative Hypotheses, Journal of Economic Integration, vol. 21, no. 3, 526-550.

Razmi, A., Rapetti, M., and Skott, P. (2012). The Real Exchange Rate as an Instrument of Development Policy, Structural Change and Economic Development, vol. 23, no.2, 151-169.

Robinson, J. (1947). Essays In The Theory Of Employment. Oxford, Basil-Blackwell.

Rodrik, D. (2008). The Real Exchange Rate and Economic Growth, Brookings Papers on Economic Activity, vol. 39, no. 2, 365-439.

Romer, D. H. (2000). Keynesian macroeconomics without the LM curve, Journal of economic perspectives, vol. 14, no. 2, 149-169.

Rojas-Suarez, L. (1987). Devaluation and Monetary Policy in Developing Countries: A General Equilibrium Model for Economies Facing Financial Constraints, IMF Staff Papers, vol. 34, no. 3, 439-470.

Schimd, M. (1982). Stagflationary effects of a devaluation in a monetary model with imported intermediated goods, Journal of Economics and Statistics, Germany, De Gruyeter, vol. 197, no. 2, 79-107.

Serrano, F., and Summa, R. (2016). Aggregate demand and the slowdown of Brazilian economic growth in 2011-2014, Nova Economia, vol. 25, 803-833.

Sheehey, E. (1986). Unanticipated inflation, devaluation and output in Latin America, World Development, vol. 14, no. 5, 665-671. 
Tadeu Lima, G., and Setterfield, M. (2008). Inflation Targeting and Macroeconomic Stability in a Post-Keynesian Economy, Journal of Post-Keynesian Economics, vol. 30, no. 3, 435-461.

Taylor, A., and Taylor, M. (2004). The Purchasing Power Parity Debate, Journal of Economic Perspectives, vol. 18 , no. $4,135-158$.

Woodford, M. (2003). Interest and Prices. Foundations of a Theory of Monetary Policy, The MIT Press.

Zhou, S. (2002). The Forward Premium Anomaly and the Trend Behavior of the Exchange Rates, Economics Letters, vol. 76, 273-79. 